\title{
DISTURBANCE HISTORY IN A LATE-SUCCESSIONAL KOREAN PINE-BROADLEAVED FOREST IN THE SOUTHERN SIKHOTE-ALIN
}

\section{T. Ya. Petrenko}

Federal Scientific center of the East Asia terrestrial biodiversity of the Far Eastern Branch, Russian Academy of Sciences, 100 let Vladivostoku street 159, Vladivostok, 690022, Russia

Botanical Garden-institute of the Far Eastern Branch, Russian Academy of Sciences,

142 Makovskii street, Vladivostok, 690024, Russia

E-mail: petrenkotya@gmail.com

\section{O. N. Ukhvatkina}

Federal Scientific center of the East Asia terrestrial biodiversity of the Far Eastern Branch, Russian Academy of Sciences, 100 let Vladivostoku street 159, Vladivostok, 690022, Russia

E-mail: ukhvatkina@biosoil.ru

\section{A. M. Omelko}

Federal Scientific center of the East Asia terrestrial biodiversity of the Far Eastern Branch, Russian Academy of Sciences, 100 let Vladivostoku street 159, Vladivostok, 690022, Russia

E-mail: omelko@biosoil.ru

\section{A. A. Zhmerenetsky}

Federal Scientific center of the East Asia terrestrial biodiversity of the Far Eastern Branch, Russian Academy of Sciences, 100 let Vladivostoku street 159, Vladivostok, 690022, Russia

E-mail: zmerenetsky@mail.ru

\section{T. Y. Epifanova}

Federal Scientific center of the East Asia terrestrial biodiversity of the Far Eastern Branch, Russian Academy of Sciences, 100 let Vladivostoku street 159, Vladivostok, 690022, Russia

E-mail: tepifanova@mail.ru

\section{ИСТОРИЯ ЕСТЕСТВЕННЫХ НАРУШЕНИЙ АРЕВОСТОЯ ПОЗДНЕСУКЦЕССИОННОГО КЕДРОВО-ШИРОКОЛИСТВЕННОГО ЛЕСА}

\section{Т. Я. Петренко}

Федеральный научный центр биоразнообразия наземной биоты Восточной Азии Дальневосточного отделения Российской академии наук,

Россия, 690022, Владивосток, np-m 100 лет Владивостоку, 159

Ботанический сад-институт Дальневосточного отделения Российской академии наук,

Россия, 690024, Владивосток, ул. Маковского, 142

E-mail: petrenkotya@gmail.com

\section{О. Н. Ухваткина}

Федеральный научный иентр биоразнообразия наземной биоты Восточной Азии Дальневосточного отделения Российской академии наук, Россия, 690022, Владивосток, np-m 100 лет Владивостоку, 159 E-mail:ukhvatkina@biosoil.ru

\section{А. М. Омелько}

Федеральный научный иентр биоразнообразия наземной биоты Восточной Азии Дальневосточного отделения Российской академии наук, Россия, 690022, Владивосток, nр-m 100 лет Владивостоку, 159 E-mail:omelko@biosoil.ru

\section{А. А. Жмеренецкий}

Федеральный научный центр биоразнообразия наземной биоты Восточной Азии Дальневосточного отделения Российской академии наук, Россия, 690022, Владивосток, пр-m 100 лет Владивостоку, 159 E-mail: zmerenetsky@mail.ru

\section{Т. Ю. Епифанова}

Федеральный научный центр биоразнообразия наземной биоты Восточной Азии Дальневосточного отделения Российской академии наук, Россия, 690022, Владивосток, пр-m 100 лет Владивостоку, 159 E-mail: t_epifanova@mail.ru 
Abstract. Relevance and objectives. Natural disturbances of the forest stand are the events that cause changes in the structure of the forest stand, the availability of resources and environmental conditions. These are key processes of the forest dynamics which ensure successful recruitment and coexistence of different species. The objective of this study was to reconstruct the disturbance history in the late-successional Korean pine-broadleaved forest of southern Sikhote-Alin. The study findings will help us to understand how forest ecosystems emerge and function without human influence and to take measures necessary to restore the forests that are already disturbed. Materials and methods. The disturbance history was reconstructed using the dendroecological approach. We analyzed 961 samples of 5 dominant species, i.e. Abies nephrolepis (Trautv.) Maxim., Betula costata Trautv., Picea jezoensis (Lindl. et Gord.) Fisch. ex Carr., Pinus koraiensis (Siebold et Zucc.) - Korean pine, and Tilia amurensis Rupr. We identified growth releases using the boundary-line release criteria. Results. For the first time it was possible to reconstruct the history of natural forest stand disturbances on the area of 5 ha for 255 years. In most of the time, periods of sharp increase in radial growth occur in no more than 5-10\% of trees. At the same time, 4 periods of major natural disturbances were revealed, i.e. 1765-1774, 1845-1849, 1880-1889, and 1960-1964. The largest one occurred in 1960-1964, when more than $20 \%$ of trees showed growth release. Conclusions. From 1750 to 2005, there were no catastrophic natural disturbances in the study area, but relative severe disturbances were detected with groups of trees having fallen out, as well as minor disturbances (loss of single trees). The loss of individual trees with subsequent formation of small gaps in the canopy contributes to continuous and stable existence of the stand. Most likely the gaps are formed due to strong winds. This provides stable generations flow of trees of different species.

Keywords: disturbance history, Korean pine-broadleaved forest, late-successional forests, dendroecology, $\mathrm{Pi}$ nus koraiensis, Far East.

For citation: Petrenko T.Ya., Ukhvatkina O.N., Omelko A.M., Zhmerenetsky A.A., Epifanova T.Y. Disturbance history in a late-successional Korean pine-broadleaved forest in the Southern Sikhote-Alin. Russian Journal of Ecosystem Ecology. 2019;4(3). Available from: https://doi.org/10.21685/2500-0578-2019-3-2

Аннотация. Актуальность и цели. Естественные нарушения древостоя - события, которые приводят к изменению его структуры, доступности ресурсов и условий среды. Это ключевые процессы в динамике леса, которые обеспечивают успешное возобновление и сосуществование различных видов. Цель исследования восстановить историю естественных нарушений в позднесукцессионном кедрово-широколиственном лесу Южного Сихотэ-Алиня. Полученный результат приведет к пониманию, как формируются и функционируют лесные экосистемы без влияния человека, и поможет в создании необходимых мер для восстановления уже нарушенных лесов. Материалы и методы. Восстановление истории естественных нарушений проводилось с помощью дендроэкологического подхода. Проанализирован 961 образец, полученный от 5 доминирующих видов: Abies nephrolepis (Trautv.) Maxim., Betula costata Trautv., Picea ajanensis (Lindl. et Gord.) Fisch. ex Carr., P. koraiensis и Tilia amurensis Rupr. Выявление периодов резкого увеличения радиального прироста проводилось с помощью методики граничной линии («boundary-line release criteria»). Результаты. Впервые восстановлена история естественных нарушений древостоя на территории 5 га, длина хронологии - 255 лет. На протяжении этого периода резкое увеличение радиального прироста произошло у менее чем $10 \%$ деревьев. При этом выявлены 4 периода времени наиболее крупных естественных нарушения: 1765-1774, 1845-1849, 1880-1889 и в 1960-1964 гг. Самое серьезное из них произошло в 1960-1964 гг., когда более 20\% деревьев резко ускорили свой прирост. Выводы. С 1750 по 2005 года на территории исследования не наблюдалось катастрофических естественных нарушений, но выявлены средние нарушения, когда выпадают группы деревьев, и мелкие нарушения (выпадение единичных деревьев). Процесс непрерывного и устойчивого существования древостоя обеспечивается за счет выпадения отдельных деревьев, образующих небольшие окна в пологе древостоя. Вероятнее всего причиной образования окон становятся сильные ветра. Данный режим обеспечивает устойчивый поток ений деревьев разных видов.

Ключевые слова: естественные нарушения, кедрово-широколиственный лес, позднесукцессионные леса, дендроэкология, Pinus koraensis, Дальний Восток

\section{Introduction}

Natural forest stand disturbances are key processes in the development of forest ecosystems that affect the growth of trees and their recruitment and allow different species to coexist within the same territory [1-4]. The term "disturbance history" in this case refers to the sequence of events (the formation of gaps in the canopy as a result of windfall, insects outbreaks, etc.) in the forest stand, which contributed to its current structure. Reconstruction of the disturbance history of a forest stand in the past is necessary to understand how the structure of the forest was formed as well as to predict its future changes $[5,6]$.

Gaps in the forest stand canopy, which are formed due to tree loss without human influence, are a sign of natural disturbances $[7,8]$. The size and frequency of the gaps, the speed of their formation are important factors that affect the formation of the forest and lead to its heterogeneity [9-11]. Gaps of different sizes in closed-canopy coniferous-broadleaved forests promote coexistence of different species [12-14]. Small gaps up to 
$100 \mathrm{~m}^{2}$ (loss of individual trees) are formed as a result of strong winds or snowfalls and create favorable conditions for reproduction and growth of shade-tolerant species [15-18]. The successful growth of light-demanding tree species requires larger gaps, over $100 \mathrm{~m}^{2}$ in size $[17,18]$.

Over the past 30 years, dendroecology methods have been actively used to study the dynamics of forest ecosystems [1, 19]. Reconstruction of disturbance history by studying the width of annual growth is the most effective approach to the reconstruction of canopy disturbance processes occurring in temperate and boreal forests [20,21].

In our paper, we reconstructed disturbance history in the late-successional Korean pinebroadleaved forest in the south of the Russian Far East. Mixed forests dominated by the Pinus koraiensis are the most valuable forest ecosystems in the Russian Far East; they show a complex spatial structure and high species diversity of flora and fauna $[22,23]$. Some parts of these forests exist without catastrophic disturbances for as long as 2000 years or more [24]. Studying such nondisturbed (by humans) and old-growth forests is a unique opportunity to understand how forest ecosystems function without human influence and to look into the processes of self-regulation of natural ecosystems.

Despite the value of these forest communities, the literature only reveals individual studies of natural disturbances in Korean pine-broadleaved forests in Primorsky Krai (the most southern part of the Russian Far East). The history of natural disturbances was reconstructed for the territory of the Sikhote-Alin Reserve, Ussuriysky Nature Reserve and Verkhneussuriysky station of the Federal Sci- entific Centre of Biodiversity of the Far Eastern Branch of the RAS $[25,26]$. In addition, 2 patterns of natural disturbances were reconstructed for Korean pine-broadleaved forests which are common in northeastern and central China [27, 28]. All of the above work, however, was carried out on small sample plots, no more than 1 ha in size, which excludes examination of all the heterogeneity and diversity of the forest. Since mixed Korean pinebroadleaved forests have a complex, multi-species composition, the size of the elementary population of each species increases. The size of elementary populations of dominant species in this area is estimated at 5-10 ha.

Thus, it is needed to do research on more extensive territories in order to thoroughly examine the entire spatial heterogeneity and understand the processes of formation of the forest stand structure. In this regard, the objective of this study was to reconstruct the history and pattern of natural disturbances in the late-successional Korean pinebroadleaved forest in the south of the Sikhote-Alin range in a sample plot of 5 ha.

\section{Materials and methods}

\section{Place of study}

The study was performed in Verkhneussuriysky station of the Verkhneussuriysky station of the Federal Scientific Centre of Biodiversity of the Far

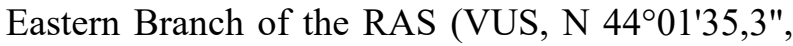
E $\left.134^{\circ} 12^{\prime} 59,8^{\prime \prime}\right)$ located on the Eastern macroslope in the south of the Sikhote-Alin mountain range in Chuguevsky district of Primorsky Krai (Fig. 1).

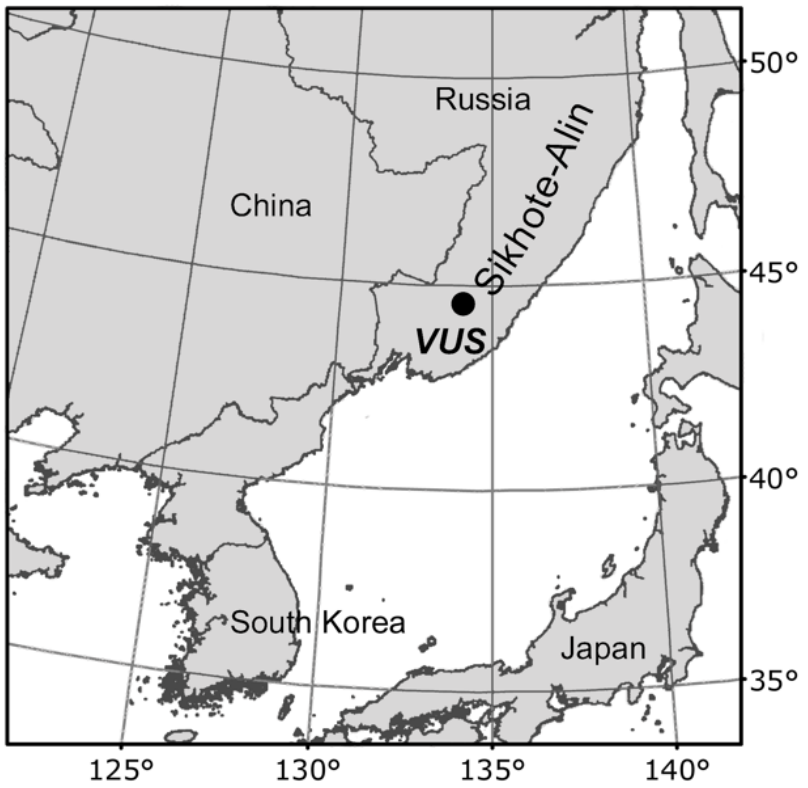

Fig. 1. Location of the Verkhneussuriysky Research Station of the Federal Scientific Center of the East Asia Terrestrial Biodiversity, FEB RAS (VUS) in Primorsky Krai 
The permanent sample plot 72-2013, 21 ha in size, established on the territory of the VUS, is located at an altitude of 700 to $900 \mathrm{~m}$ above sea level, in the area of transition from the Korean pinebroadleaved to spruce-fir forest [29]. No fires or anthropogenic impact affected this area during the last 2000 years [30]. The stand is formed by 12 tree species, 5 of which are dominant: Abies nephrolepis, Betula costata, Picea jezoensis, Pinus koraiensis and Tilia amurensis. The territory is characterized by monsoon climate; precipitation falls predominantly in summer. The average annual temperature is $0.9^{\circ} \mathrm{C}$, the average annual precipitation is $832 \mathrm{~mm}$ [31].

\section{Data collection}

Samples were collected on sample plot 72 2013 in 2014-2018. The entire plot was divided into squares of $50 \times 50 \mathrm{~m}$. Squares for core samplings were allotted chequerwise in a part of the plot. On each of the selected squares core samples from all trees of the 5 dominant species were obtained (trees with diameter more than $10 \mathrm{~cm}$ at the height of $1.3 \mathrm{~m}$ i.e. virginal and generative). Core samples were taken at a height of $1-1.3 \mathrm{~m}$. In the cases when an obtained sample was almost totally rotten (over $2 / 3$ of the tree radius), the sample was excluded from further analysis. When taking the core sample of each tree, the tree species, the tree number, the core sampling height, the tree diameter at the sampling height, and the ontogenetic stage of the tree were specified. Cross-sections were obtained from dead, already fallen trees to expand the period examined. In total 961 dendrochronological samples (cores and cross sections) of the trees from virginile age to the old-aged generative state were collected: Abies nephrolepis - 233 samples, Betula costata - 98 samples, Picea jezoensis - 316 samples, Pinus koraiensis - 171 samples, and Tilia amurensis - 143 samples.

\section{Dendrochronological material processing}

Before analyzing the dendrochronological data, all samples were dried, sanded and processed for contrast enhancement. Then Velmex ${ }^{\circledR}$ TA Measurement System (Bloomfield, USA) was used to count the number of annual rings and to measure the width of the rings within the accuracy of 0.01 $\mathrm{mm}$ for each core and cross section. After that, cross-dating was performed in order to identify the "lost" rings and accurately determine the beginning date of the tree life. Processing was performed using Cofecha [32] and TSAP-DOS (Rinntech ${ }^{\circledR}$, Heidelberg, Germany) software.

\section{Waves of recruitment}

Age spectra for each species were constructed to study tree species recruitment waves. When constructing the age spectra of deciduous trees, the trees of the last phase of the virginile age as well as young, middle and old generative age trees were used. The analysis of coniferous species involved trees of all ontogenetic stages, starting with the immature one. Immature plants were studied in the vicinity of the sample plot, since the exact study of the absolute age requires obtaining cross sections of young trees near the root.

Since the height of the core samples taking was $1.3 \mathrm{~m}$, it was necessary to estimate the approximate age at which the trees reached this height. The height of 1.3 meters corresponds to the average height of trees of the intermediate phase of immature age stage [33-35]. In old-growh Korean pine-broadleaved forests Pinus koraiensis on average reaches a height of $1.3 \mathrm{~m}$ at 69 years, Abies nephrolepis - at 51 year, and Picea jezoensis at 43 years [36]. No studies aimed at the identification of age of the deciduous species Betula costata and Tilia amurensis in different phases of the immature stage were conducted, but the overall range of age state is known: 1-43 years for Betula costata and 13-37 years for Tilia amurensis [30]. It is also known that Tilia amurensis is not able be suppressed for more than 20 years [37], and Betula costata - for more than 20-30 years [38]. Based on this information, we can roughly estimate the average age of trees at a height of $1.3 \mathrm{~m}$ for Tilia amurensis at 20-25 years, and for Betula costata at 25-30 years. Thus, the age of trees for creating the spectrum was calculated by adding the annual rings counted on the core and the approximate average age of reaching a height of $1.3 \mathrm{~m}$.

\section{Retracing the history of natural disturbances}

To reconstruct the disturbance history we used the Black and Abrams's [39, 40] boundary-line release criteria, which is the improved Nowacki and Abrams's method [41]. To identify periods of sharp increase in radial growth (releases), a special boundary-line function is selected, which describes the maximum possible change in growth $(\% G C)$ depending on the prior growth. The relative change in growth is calculated according to the formula:

$$
\% G C=(M 1-M 2) / M 1 * 100
$$

where $M 1$ is the prior (averaged growth over the last 10 years, including the current year), and $M 2$ is the averaged growth over the next 10 years.

Further, the values of the growth change $(\% C G)$ for each year are compared with the maximum values obtained from the boundary-line func- 
tion equation. If the value of the growth change exceeds some preset part of the maximum value, it is considered to be a growth release. For the minor release it is necessary that the value be $20-49 \%$ of the maximum. The release is considered major when the value is $50 \%$ or more of the maximum. The period of increase in radial growth is stated when for 5 or more consecutive years the value was at least $20 \%$ of the maximum.

The statistical package TRADER [42] in the RStudio ${ }^{\circledR}$ software was used to select the boundary-line function, identify release periods and analyze the waves of recruitment. The method of direct Fourier transform (spectral analysis, StatSoft ${ }^{\circledR}$
STATISTICA) was used to identify the periodicity in the disturbance history.

\section{Results}

\section{The selection of boundary-line function}

In total 112795 measurements were obtained in the result of the annual growth width measurement: 40397 for Picea jezoensis, 14872 for Abies nephrolepis, 38975 for Pinus koraiensis, 9562 for Tilia amurensis, and 8989 for Betula costata. A boundary line, which is given by an exponential function, was chosen for all trees (Fig. 2).
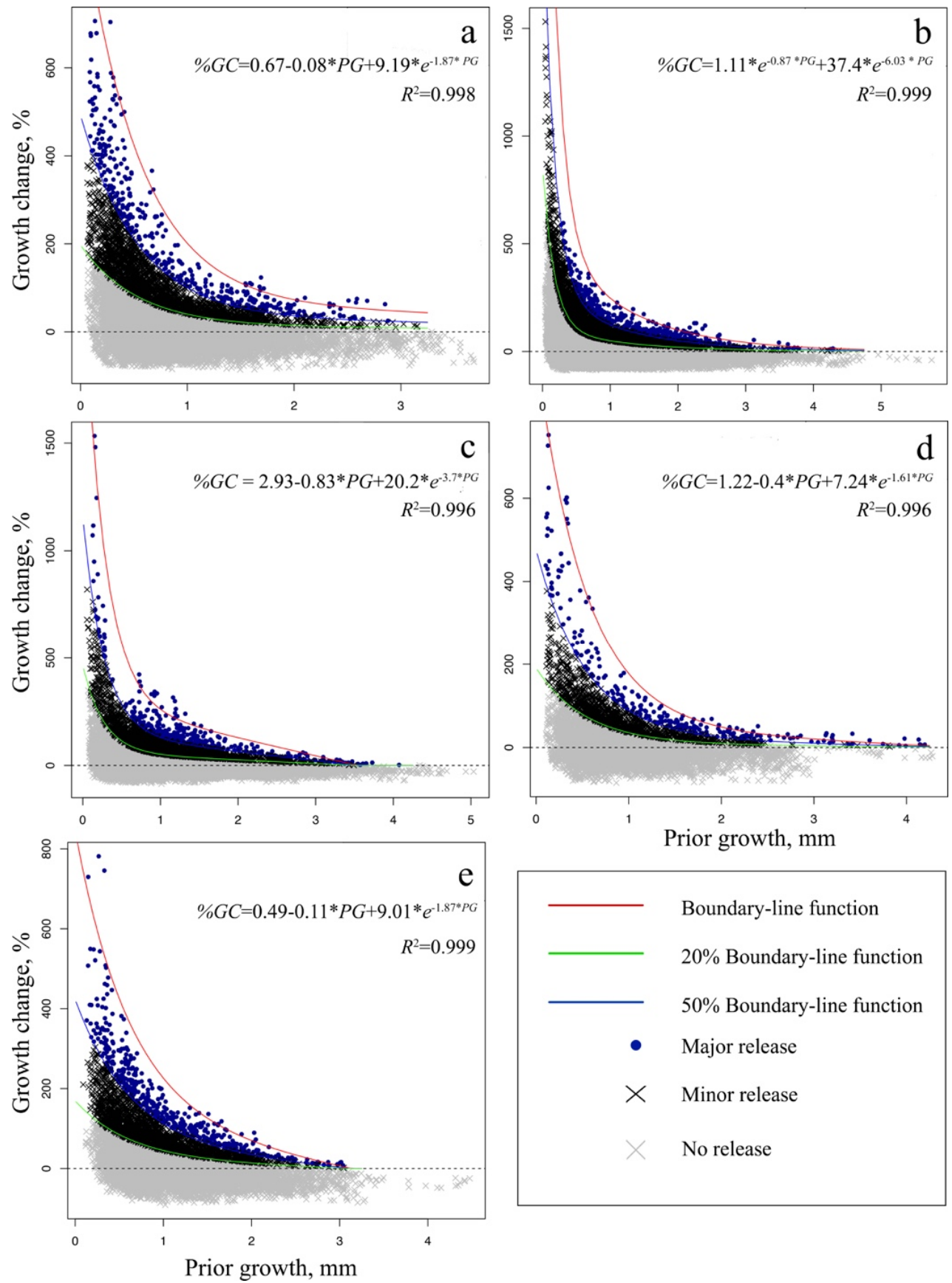

Prior growth, mm

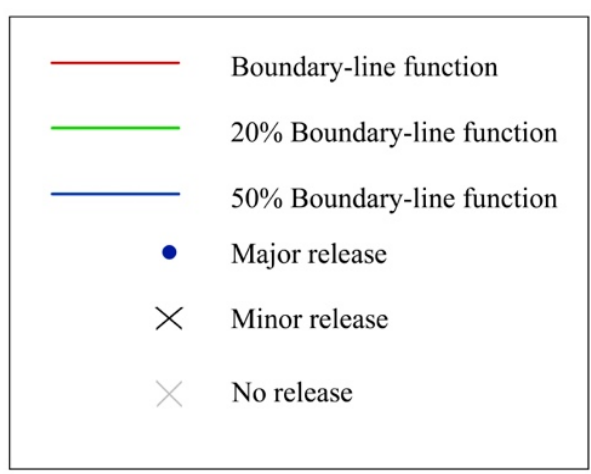

Fig. 2. Boundary-line functions: $a$ - Abies nephrolepis; $b$-Picea jezoensis; $c$ - Pinus koraiensis; $d$ - Betula costata; $e-$ Tilia amurensis. The red line is the boundary-line function, the blue line is $50 \%$ of the boundary line (major releases boundary), the green line is $20 \%$ of the boundary line (minor releases boundary) 
If the annual tree ring is wide (large prior growth), it is not able to change greatly, i.e. a tree with the ring of $4 \mathrm{~mm}$ cannot have a 2-3 times wider ring; at the same time, the smaller the tree growth is, the more it can increase - an average growth of $0.2 \mathrm{~mm}$ can increase to $2-5 \mathrm{~mm}$, i.e. 10 to 25 times (see Fig. 2). The most dramatical changes in radial growth are typical for Picea jezoensis and Pinus koraiensis, where the growth can increase by as much as $1500 \%$ (Fig. 2,b,c). Then this growth declines strongly, and with a previous growth of $0.5 \mathrm{~mm}$ or more, the change in growth is comparable to other species. For Tilia amurensis, Abies nephrolepis and Betula costata, the maximum change in radial growth is not more that $800 \%$.

\section{Reconstruction of the disturbance history}

Based on 961 sample we reconstructed disturbance history of the recent 255 years, from 1750 to 2005 - a time span when the number of the samples analyzed is 50 or more (Fig. 3). A total of 1102 release periods were identified (see Table 1). Most releases observed were minor (20\%-threshold of the boundary function) (Table 1). Major releases $50 \%$ of the boundary function - were less frequent (14.4\% of the total number of releases). Intense releases were most often found for Betula costata.

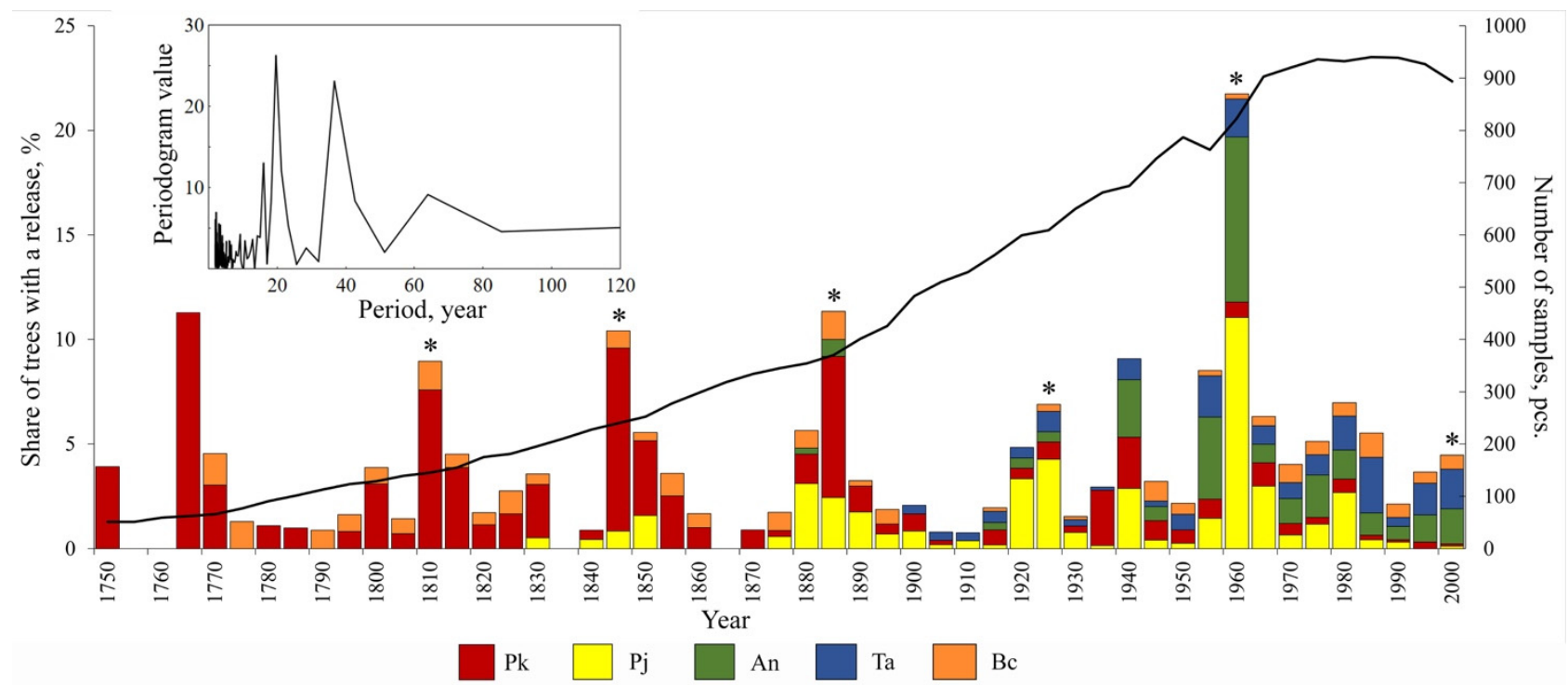

Fig. 3. Disturbance history in old-growth Korean pine-broadleaved forest. The black line is the number of samples in the analysis. Asterisks in the diagram show the 36-year periods of natural disturbances. Inset in the upper left corner shows the results of spectral analysis of the disturbance history. Tree species symbols: Pk - Pinus koraiensis, $\mathrm{Pj}$ - Picea jezoensis, An - Abies nephrolepis, Ta - Tilia amurensis, Bc - Betula costata

Table 1

Number of detected growth releases

\begin{tabular}{|l|c|c|c|}
\hline \multicolumn{1}{|c|}{ Species } & Share of minor releases, \% & Share of major releases, \% & $\begin{array}{c}\text { Average number } \\
\text { of releases per 1 tree }\end{array}$ \\
\hline Picea jezoensis & 89.14 & 10.86 & 0.96 \\
\hline Pinus koraiensis & 87.90 & 12.10 & 1.56 \\
\hline Abies nephrolepis & 85.47 & 14.53 & 1.00 \\
\hline Betula costata & 78.18 & 21.82 & 1.12 \\
\hline Tilia amurensis & 81.55 & 18.45 & 1.45 \\
\hline
\end{tabular}

Most often, no more than $5 \%$ of trees (see Fig. 3) show a release (both minor and major). Four release waves were revealed in the forest stand, within the entire reporting period, with more than $10 \%$ of trees showing release. This proves the presence of moderate natural disturbances.

First of such disturbances were observed in 1765-1769 and 1845-1849, when $11.3 \%$ and $10.4 \%$ of trees, respectively, showed growth release (see Fig. 3). The next peak was in 1885-1890, when $11.4 \%$ of trees responded to improved light conditions. The "severest" natural disturbance occurred in 1960-1965, resulting in a growth release in $21.7 \%$ of trees. A weak disturbance probably occurred in 1940-1945, but the number of the trees that responded was a bit under $10 \%(9.1 \%$ of trees $)$. Spectral analysis of the disturbance history showed the periodicity of 19 and 36 years (see Fig. 3). 
The greatest number of release periods was observed in Pinus koraiensis (1.6 releases per tree) and Tilia amurensis (1.5 releases per tree) (see Table 1). Picea jezoensis and Abies nephrolepis showed the least number of releases, on average 1 per tree. At the same time, after 1875, most releases were observed in Picea jezoensis trees due to the largest share of the samples of this species in the analysis (see Fig. 3). In the first part of the diagram, however, it is mainly Pinus koraiensis that shows releases, which is due to the longest lifespan of the species.

\section{Waves of recruitment}

Diagrams of absolute age distribution can help to identify the waves of the plants recruitment (Fig. 4). All species have more or less distinct recruitment waves. In coniferous species, trees have been stud- ied starting from the immature ontogenetic stage, therefore the highest peaks occurred in the last 10 15 years (Fig. $4, a, b, c)$.

In Pinus koraiensis, the maximum peak of young trees was observed in 1990-1999. Also, active recruitment occurred in 1700-1715 (maximum in 1705), and 2 small peaks were observed in 1745 and 1795 (see Fig. 4,a). In Picea jezoensis, the last peak of recruitment occurred in 1995-2004, and there had been 2 major peaks earlier, the first in 1805-1814, and the second (maximum) - in 1845 (see Fig. 4,b). The maximum peak in young Abies nephrolepis trees was observed in 1995-2004. Active recruitment also occurred in 1875-1889 and a small peak was observed in 1895 (see Fig. 4,b). Deciduous trees had peaks of recruitment in 19151924 and in 1935-1944 in Betula costata, and in 1915-1924 - in Tilia amurensis (Fig. 4,d,e).

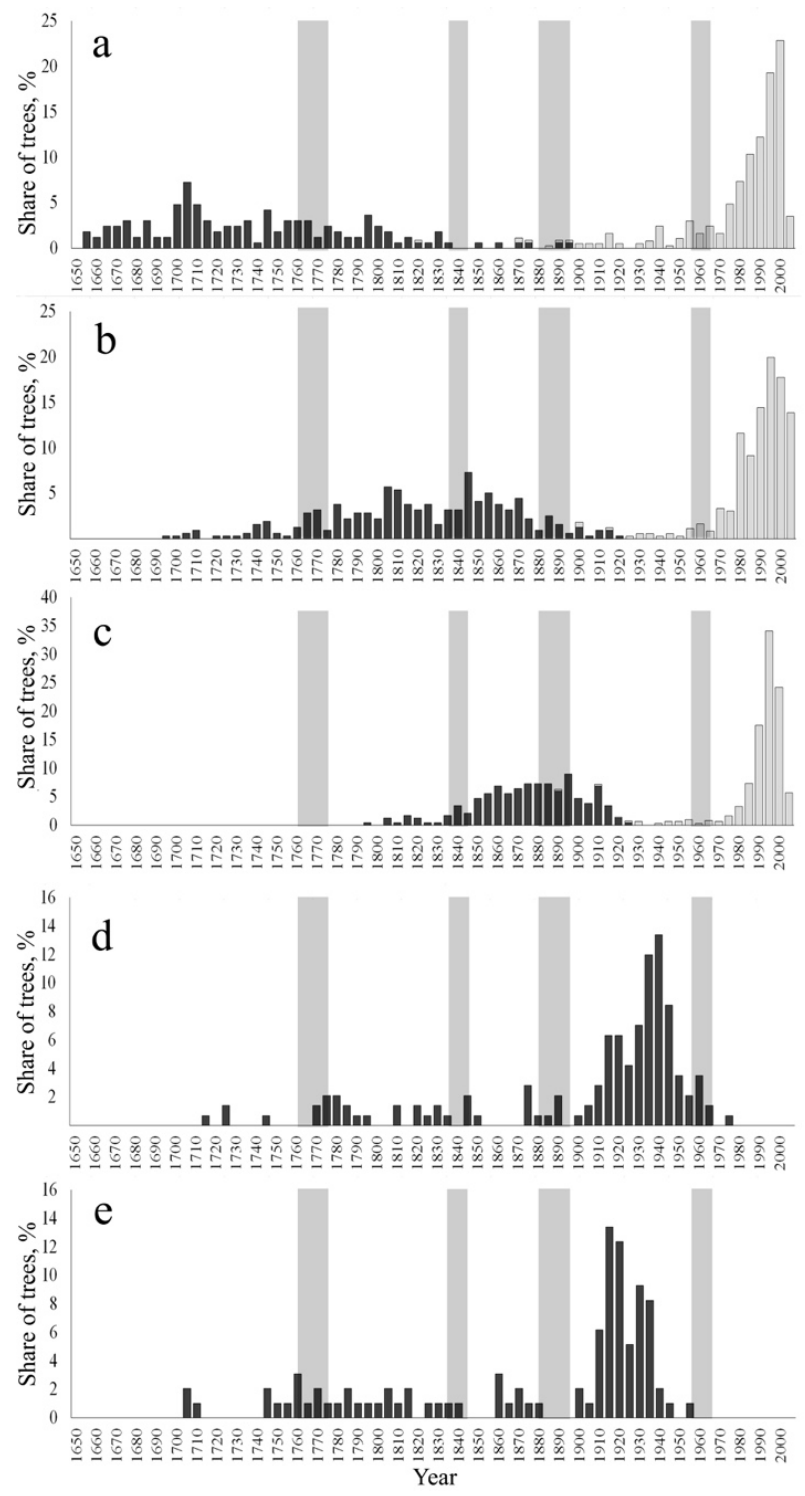

Fig. 4. Waves of recruitment: $a$ - Pinus koraiensis; $b$-Picea jezoensis; $c$ - Abies nephrolepis; $d$ - Tilia amurensis; $e-$ Betula costata. Light bars stand for trees of the immature and first and second phases of the virginal ontogenetic stage. Dark bars stand for trees of the third phase of the virginal and the generative ontogenetic stage. Gray areas show the periods of the strongest natural disturbances 


\section{Discussion}

For the first time the disturbance history for the late-successional Korean pine-broadleaved forest in the southern part of the Sikhote-Alin range on the area of 5 ha was reconstructed. Reconstruction has shown that since 1750 the studied plot has not seen severe disturbances with the mass loss of trees (see Fig. 3). It is also known that in the last 2000 years there were no forest fires, either anthropogenic or of natural origin, in the study area [30].

The reconstructed disturbance history showed that releases were most often observed in 5-10\% of trees (see Fig. 3). Since the number of dominant trees per 1 ha is on average 659.3 [30], the average response to improved conditions occurs in 43 trees/ha. This suggests that most often only individual trees die in the forest stand. However, despite the permanent loss of individual species, greater natural disturbances occur from time to time (see Fig. 3). During the entire time of study, 4 periods of the largest disturbances in the study area were identified: 1765-1774 (11.3\%), 1845-1849 (10.4\%), 1885-1889 (11.4\%), and 1960-1964 (21.7\%). 36-year periods typical of the forest stand were identified in the peaks of 1810 1814, 1845-1849 (10.4 \%), 1885-1889, 19251929, 1960-1964, and 2000-2004 (see Fig. 3). A less pronounced peak occurred in 1810-1814 (less than $10 \%$ of trees responded to changing conditions), which can be explained by the fact that only two tree species were involved in the analysis.

Synchronized release periods in a large number of trees mean that medium-sized gaps were formed at this time. These disturbances are likely to be caused by strong winds, and the resulting gaps are up to $200-250 \mathrm{~m}^{2}$ in size $[25,43,44]$. The formation of gaps in this stand is mostly due to Picea jezoensis [45].

The formation of small gaps is an important stage in the development of the forest stand, as these gaps often make it possible to survive for the shade-tolerant species, which are able to withstand the lack of light for a long time and grow in the context of insufficient solar radiation [8, 46, 47]. Within the studied territory such species are coniferous trees, i.e. Picea jezoensis and Abies nephrolepis as well as Pinus koraiensis [48]. When a gap appears in the stand, young trees show a release, sometimes accelerating their growth up to $1500 \%$ (see Fig. 3,b,c), which allows them to continue growing. Natural disturbances of this scale allow for continuous active recruitment of the species and their domination in the canopy of the forest stand (see Fig. 4). But in some periods peaks of recruitment are observed. Synchronization between disturbances and recruitment the most evident in Picea jezoensis: peaks of germination occurred in 1805-1814 and in 1845, which corresponds to the disturbances of 1810-1814 and 1845-1849 (see Fig. 3, $b, 4$ ).

Despite the fact that the maximum peaks in Picea jezoensis, Abies nephrolepis and Pinus koraiensis are not synchronized with each other, peaks often coincide in time with disturbances in all shade-tolerant species (see Fig. 3, 4). This lack of synchronization is most likely due to the large difference in the life span of these species. Pinus koraiensis trees lives up to 500 years (on average 300 to 400 years) [49], the maximum age of Picea jezoensis trees is $300-350$ years, and the average age is 200-250 years [50], whereas the maximum age of Abies nephrolepis is 150 years with the average age 100-120 years [34].

Due to natural disturbances, the recruitment of trees is synchronized not only in time but also in space. The distribution of immature plants over the sample plot is explained specifically by the formation of the stand canopy gaps, which create favorable conditions for the survival of immature and virginal trees, as well as by a suitable substrate for the recruitment of certain species $[24,36]$.

The natural disturbance of the stand in 1960 1964 is the largest disturbance in the observed period (see Fig. 3). In total, $21.7 \%$ of trees showed a release during this period (see Fig. 3). Many studies show that medium-scale disturbances resulting in the formation of sufficiently large gaps up to $250 \mathrm{~m}^{2}$ [24] in the old-aged stand enable the recruitment of light-loving species [51-54]. Lightdemanding species in this study include 2 deciduous species, i.e. Tilia amurensis and Betula costata [48]. The main peaks of recruitment of Tilia amurensis and Betula costata were observed 20 years before the largest major disturbance of 1960-1965 (Fig. 4,d,e). Most likely, stand disturbances in this case do not affect the direct germination of seeds but contribute to the survival of the young trees of 20-30 years of age.

During the same period, a rather severe natural disturbance occurred in the relatively more northern part of Primorsky Krai, on the territory of the Sikhote-Alin Reserve [25, 26], as well as in the fir-spruce forests of Primorsky Krai [55]. Synchronization of natural disturbances at different study sites located $180 \mathrm{~km}$ from each other is most likely a consequence of the impact of a major process of a regional scale. Such a serious disturbance could be probably caused by Typhoon Emma, which hit Primorsky Krai in 1956 [56]. It was one of the strongest typhoons in terms of wind speed, which could cause such major windthrows in the study area. 


\section{Conclusion}

Our study made it possible to reconstruct for the first time disturbance history for 255 years for the late-successional Korean pine-broadleaved forest on the territory of 5 ha in the south of the Russian Far East. From 1750 to 2005, no catastrophic disturbances (mass losses of trees) occurred within the territory. During the entire reconstruction period, small-scale natural disturbances were observed, when single trees are lost. This loss of individual trees, forming small gaps in the canopy, promotes continuous and sustainable existence of the stand. From time to time, relatively more severe disturbances take place, with groups of trees falling out, forming larger gaps allowing for the survival of deciduous trees. The most likely reason for the formation of gaps of this size is strong winds. This pattern of natural disturbances in the late-successional Korean pinebroadleaved forest provides a stable generations flow of tree species with different environmental needs and life strategies.

\section{Acknowledgements}

The work was carried out with financial support from the Russian Foundation for Basic Research (grants No. 18-04-00278 and No. 18-04-00120).

\section{References}

1. Pickett, S. T. A. The ecology of natural disturbance and patch dynamics / S. T. A. Pickett, P. S. White. New York : Acad. Press, 1985. $-418 \mathrm{p}$.

2. Frelich, L. E. Natural disturbance regimes in hemlock hardwood forests of the upper great lakes region / L. E. Frelich, C. G. Lorimer // Ecological Monographs. - 1991. - Vol. 61. - P. 145-164.

3. Kubota, Y. Spatial pattern and regeneration dynamics in a temperate Abies-Tsuga forest in south-western Japan / Y. Kubota // Journal of Forest Research. - 2006. - Vol. 11. - P. 191-201.

4. Past, current and future fire frequency in the Canadian boreal forest: implications for sustainable forest management / Y. Bergeron, M. Flannigan, S. Gauthier, A. Leduc, P. Lefort // Ambio. - 2004. - Vol. 33. - P. 356-360.

5. Girardin, M. P. Radial growth analysis of Larix laricina from the Lake Duparquet area. Quebec, in relation to climate and larch sawfly outbreaks / M. P. Girardin, J. Tardif, Y. Bergeron // Ecoscience. - 2001. - Vol. 8. - P. 127-138.

6. Kuuluvainen, T. Natural variability of forests as a reference for restoring and managing biological diversity in boreal Fennoscandia / T. Kuuluvainen // Silva Fennica. - 2002. - Vol. 36. - P. 97-125.

7. Leemans, R. Canopy gaps and establishment patterns of spruce (Picea abies (L.) Karst.) in two old-growth coniferous forests in central Sweden / R. Leemans // Plant Ecol. - 1991. - Vol. 93. - P. 157-165.

8. Yamamoto, S. Forest Gap Dynamics and Tree Regeneration / S. Yamamoto // J. For. Res. - 2000. - Vol. 5. P. 223-229.

9. Denslow, J. S. Tropical rainforest gaps and tree species diversity / J. S. Denslow // Annual Review of Ecology, Evolution, and Systematics. - 1987. - Vol. 18. - P. 431-451.

10. Liu, Q. J. Structure and dynamics of the subalpine coniferous forest on Chang-bai mountain / Q. J. Liu // China. Plant Ecology. - 1997. - Vol. 132. - P. 97-105.

11. Canham, C. D. An index for understory light levels in and around canopy gaps / C. D. Canham // Ecology. - 1998. Vol. 69. - P. 1634-1638.

12. Runkle, J. R. The Ecology of Natural Disturbance and Patch Dynamics / J. R. Runkle. - Orlando : Academic Press, 1985. $-472 \mathrm{p}$.

13. Foster, D. R. Landscape patterns and legacies resulting from Large, infrequent forest disturbances / D. R. Foster, D. H. Knight, J. F. Franklin // Ecosystems. - 1998. - Vol. 1. - P. 497-510.

14. Turner, M. G. Factors influencing succession: lessons from large, infrequent natural disturbances / M. G. Turner, W. L. Baker, C. J. Peterson, R. K. Peet // Ecosystems. - 1998. - Vol. 1. - P. 511-523.

15. Aakala, T. Temporal variability of deadwood volume and quality in boreal old-growth forests / T. Aakala // Silva Fenn. - 2011. - Vol. 45. - P. 969-981.

16. Runkle, J. R. Treefalls revisited: gap dynamics in the southern Appalachians / J. R. Runkle, T. C. Yetter // Ecology. - 1987. - Vol. 68. - P. 417-424.

17. Kobe, R. K. Juvenile tree survivorship as a component of shade tolerance / R. K. Kobe, S. W. Pacala, J. A. Silander, C. D. Canham // Ecological Applications. - 1995. - Vol. 5. - P. 517-532.

18. Liu, Q. J. Structure and dynamics of the subalpine coniferous forest on Chang-bai mountain / Q. J. Liu // China. Plant Ecology. - 1997. - Vol. 132. - P. 97-105.

19. Kulakowski, D. P. Changes in forest structure and the relative importance of climatic stress as a result of suppression of avalanche disturbances / D. P. Kulakowski, C. Rixen, P. Bebi // For. Ecol. Manag. - 2006. - Vol. 223 (1). P. 66-74.

20. Splechtna, B. E. Disturbance history of a European old-growth mixed-species forest - a spatial dendroecological analysis / B. E. Splechtna, G. Gratzer, B. A. Black // J. Veg. Sci. - 2005. - Vol. 16. - P. 511-522.

21. Black, A. B. Properties of boundary-line release criteria in North American tree species / A. B. Black, M. D. Abrams, J. S. Rentch, P. J. Gould // Ann. For. Sci. - 2009. - Vol. 66 (2). - P. 205-216. 
22. Koryakin, N. V. Korean pine-broadleaved forests of the Russian Far East / N. V. Koryakin. - Khabarovsk : Federal State Institution "Far East Research Institute of Forestry", 2007. - 359 p. [in Russian]

23. Kudinov, A. I. Korean pine-broadleaved forests of Southern Primorye and their dynamics / A. I. Kudinov. - Vladivostok : Dalnauka, 2004. - 369 p. [in Russian]

24. Omelko, A. M. From young to adult trees: how spatial patterns of plants with different life strategies change during age development in an old-growth Korean pine-broadleaved forest / A. M. Omelko, O. N. Ukhvatkina, A. A. Zhmerenetsky, T. Ya. Petrenko // For. Ecol. and Manage. - 2018. - Vol. 411. - P. 46-66.

25. Ishikawa, Y. Disturbance history and tree establishment in old-growth Pinus koraiensis-hardwood forests in the Russian Far East / Y. Ishikawa, P. V. Krestov, K. Namikawa // Journal of Vegetation Science. - 1999. - Vol. 10. P. 439-448.

26. Ukhvatkina, O. N. Influence of severe disturbances in stands of Korean pine-broadleaved forests on the process of natural regeneration / O. N. Ukhvatkina, A. M. Omelko, P. V. Krestov, A. A. Zhmerenetsky // Journal of the Siberian Federal University : Biology. - 2011. - № 4 (4). - P. 416-431. [in Russian]

27. Disturbance and regeneration dynamics of a mixed Korean pine dominated forest on Changbai Mountain, NorthEastern China / Y. Zhang, I. Drobyshev, L. Gao, X. Zhao, Y. Bergeron // Dendrochronologia. - 2014. - Vol. 32. P. 21-31.

28. Disturbance history of an old-growth subalpine larch forest in the Qinling Mountains, north-central China / Q. Zhou, H. Shi, C. Liu, K. Zhang, Q. Zhang, H. Dang // Dendrochronologia. - 2018. - Vol. 50. - P. 91-97.

29. Kolesnikov, B. P. Korean pine forests of the Far East / B. P. Kolesnikov // Works of FEF SB AN USSR. Botanical Series. - 1956. - № 2, vol. 4. - 262 p. [in Russian]

30. Omelko, A. M. Disturbance history and natural regeneration of an old-growth Korean pine-broadleaved forest in the Sikhote-Alin mountain range, Southeastern Russian / A. M. Omelko, O. N. Ukhvatkina, A. A. Zhmerenetsky // Forest Ecology and management. - 2016. - Vol. 360. - P. 221-234.

31. Kozhevnikova, N. K. Dynamics of weather and climate characteristics and ecological functions of a small forest basin / N. K. Kozhevnikova // Siberian Journal of Ecology. - 2009. - № 5. - P. 693-703. [in Russian]

32. Holmse, R. L. Computer-assisted quality control in tree-ring dating and measurement / R. L. Holmse // Tree-Ring Bull. - 1983. - Vol. 43. - P. 69-78.

33. Komarova, T. A. Ontomorphogenesis of Korean pine (Pinus koraiensis Sieb. Et Zucc.) in the mid-mountain belt of the southern Sikhote-Alin / T. A. Komarova, O. N. Ukhvatkina, A. D. Trofimova // Bul. Bot. Garden-Institute FEB RAS. - 2010. - № 5. - P. 81-92. [in Russian]

34. Komarova, T. A. Ontomorphogenesis of white fir (Abies nephrolepis (Trautv.) Maxim.) in the mid-mountain belt of southern Sikhote-Alin / T. A. Komarova, O. N. Ukhvatkina, A. D. Trofimova, U-San. Kim // Bulletin of the Botanical Garden-Institute of the Far Eastern Branch of the Russian Academy of Sciences. - № 5. - P. 93-101. [in Russian]

35. Ukhvatkina, O. N. Features of the ontogenesis of Picea ajanensis (Lindl. Et Gord.) Fisch. ex Carr. in the midmountain zone of the South Sikhote-Alin / O. N. Ukhvatkina, T. A. Komarova, A. D. Trofimova // Bulletin of Moscow State Forest University. - 2010. - № 3. - P. 169-173. [in Russian]

36. Omelko, A. M. Regeneration of coniferous species in Korean pine-broadleaved forests of the south of the Russian Far East: age structure of undergrowth / A. M. Omelko, O. N. Ukhvatkina, A. A. Zhmerenetsky, V. S. Gusev // Basic research: Biological sciences. - 2013. - № 11. - P. 443-447. [in Russian]

37. Zhmerenetsky, A. A. The formation of Tilia amurensis Rupr. population mosaic in the Korean pine-broadleaved forest in the south of the Russian Far East / A. A. Zhmerenetsky, A. M. Omelko, O. N. Ukhvatkina, T. Y. Petrenko // Russian journal of ecosystem ecology. - 2018. - Vol. 3 (1). - P. 1-11. [in Russian]

38. Ontogenetic and spatial structure of c Betula costata (Betulaceae) enopopulation in the non-disturbed Korean pinebroadleaved forest in the south of the Russian Far East / A. A. Zhmerenetsky, A. M. Omelko, O. N. Ukhvatkina, T. Ya. Petrenko, L. A. Sibirina // Plant resources. - 2018. - № 54 (2). - P. 260-279. [in Russian]

39. Black, B. A. Use of boundary-line growth patterns as a basis for dendroecological release criteria / B. A. Black, M. D. Abrams // Ecological Applications. - 2003. - Vol. 13. - P. 1733-1749.

40. Black, B. A. Development and application of boundary-linerelease criteria / B. A. Black, M. D. Abrams // Dendrochronologia. - 2004. - Vol. 22. - P. 31-42.

41. Nowacki, G. J. Radial-growth averaging criteria for reconstructing disturbance histories from presettlement-origin oaks / G. J. Nowacki, M. D. Abrams // Ecol. Monogr. - 1997. - Vol. 67. - P. 225-249.

42. Altman, J. TRADER: A package for Tree Ring Analysis of Disturbance Events in R / J. Altmana, P. Fibich, J. Dolezal, T. Aakala // Dendrochronologia. - 2014 . - Vol. 32. - P. 107-112.

43. Yang, G. T. Picea-Abies forests of the northeast China / G. T. Yang, H. Erich, B. Sun, J. Zhang // Bull. Bot. Res. 1994. - Vol. 14. - P. 313-328.

44. Zielonka, T. A tree-ring reconstruction of wind disturbances in forest of the Slovakian Tatra Mountains, Western Carpithains / T. Zielonka, J. Holeksa, P. Fleischer, P. Kapusta // Journal of Vegetation Science. - 2010. - Vol. 21. P. 31-42.

45. Ukhvatkina, O. N. Natural disturbances regime as a factor determining the formation of a stand of Korean pinebroadleaved forest in the south of the Russian Far East / O. N. Ukhvatkina, A. M. Omelko, A. A. Zhmerenetsky, V. S. Gusev // Journal of the Siberian Federal University: Biology. - 2015. - № 4 (8). - P. 441-458. [in Russian] 
46. Zielonka, T. The dynamics of a mountain mixed forest under wind disturbances in the Tatra Mountains, central Europe - a dendroecological reconstruction / T. Zielonka, P. Malcher // Can. J. For. Res. - 2009. - Vol. 39. P. 2215-2223.

47. Zhao, X. H. Correlations between canopy gaps and species diversity in broad-leaved and Korean pine mixed forests / X. H. Zhao, C. Y. Zhang, J. M. Zheng // Frontiers of Forestry in China. - 2006. - Vol. 4. - P. 372-378.

48. Chumachenko, S. I. Construction of a quantitative scale of shade tolerance of some dominant tree species in the middle part of Primorsky Krai / S. I. Chumachenko, A. I. Yakovleva // Bulletin of the Irkutsk state Agriculture Academy. - 2014. - Vol. 61. - P. 74-80. [in Russian]

49. Ukhvatkina, O. N. Features of the life strategy of the Korean pine (Pinus koraiensis Sieb. Et Zucc.) in the latesuccessional coniferous-deciduous forest in southern Sikhote-Alin / O. N. Ukhvatkina, A. M. Omelko // Tomsk Bulletin State University. Biology. - 2016. - Vol. 4 (36). - P. 164-179. [in Russian]

50. Usenko, N. V. Trees, shrubs and vines of the Far East / N. V. Usenko. - Khabarovsk : Khabarovsk Book Publishing House, 1984. - 272 p. [in Russian]

51. Dejan, F. Disturbance history and dynamics of an old-growth mixed species mountain forest in the Slovenian Alps / F. Dejan, N. Thomasa, D. Jurij // For. Ecol. Manage. - 2009. - Vol. 257. - P. 1893-1901.

52. Disturbance history of an old-growth sub-alpine Picea abies stand in the Bohemian Forest, Czech Republic / M. Svoboda, P. Janda, T. A. Nagel, S. Fraver, J. Rejzek, R. Ba // J. Veg. Sci. - 2012. - Vol. 23. - P. 86-97.

53. Nagel, T. A. Disturbance, life history traits, and dynamics in an old-growth forest landscape of southeastern Europe / T. A. Nagel, M. Svoboda, M. Kobal // Ecol. Appl. - 2014. - Vol. 24. - P. 663-679.

54. Petritan, A. M. Dendroecological reconstruction of disturbance history of an old-growth mixed sessile oak-beech forest / A. M. Petritan, O. Bouriaud, D. C. Frank, I. C. Petritan // J. Veg. Sci. - 2017. - Vol. 28. - P. 318-331.

55. Kozin, E. K. Mass decay of dark coniferous forests as a natural stage of their age development / E. K. Kozin // Bull. Bot. Garden - Institute FEB RAS. - 2013. - Vol. 10. - P. 4-14. [in Russian]

56. Longshore, D. Encyclopedia of Hurricanes, Typhoons, and Cyclones / D. Longshore // Infobase Publishing. 2008. $-481 \mathrm{p}$.

\section{References}

1. Pickett S. T. A., White P. S. The ecology of natural disturbance and patch dynamics. New York: Acad. Press, 1985,418 p.

2. Frelich L. E., Lorimer C. G. Ecological Monographs. 1991, vol. 61, pp. 145-164.

3. Kubota Y. Journal of Forest Research. 2006, vol. 11, pp. 191-201.

4. $\quad$ Bergeron Y., Flannigan M., Gauthier S., Leduc A., Lefort P. Ambio. 2004, vol. 33, pp. 356-360.

5. Girardin M. P., Tardif J., Bergeron Y. Ecoscience. 2001, vol. 8, pp. 127-138.

6. Kuuluvainen T. Silva Fennica. 2002, vol. 36, pp. 97-125.

7. Leemans R. Plant Ecol. 1991, vol. 93, pp. 157-165.

8. Yamamoto S. J. For. Res. 2000, vol. 5, pp. 223-229.

9. Denslow J. S. Annual Review of Ecology, Evolution, and Systematics. 1987, vol. 18, pp. 431-451.

10. Liu Q. J. China. Plant Ecology. 1997, vol. 132, pp. 97-105.

11. Canham C. D. Ecology. 1998, vol. 69, pp. 1634-1638.

12. Runkle J. R. The Ecology of Natural Disturbance and Patch Dynamics. Orlando: Academic Press, 1985,472 p.

13. Foster D. R., Knight D. H., Franklin J. F. Ecosystems. 1998, vol. 1, pp. 497-510.

14. Turner M. G., Baker W. L., Peterson C. J., Peet R. K. Ecosystems. 1998, vol. 1, pp. 511-523.

15. Aakala T. Silva Fenn. 2011, vol. 45, pp. 969-981.

16. Runkle J. R., Yetter T. C. Ecology. 1987, vol. 68, pp. 417-424.

17. Kobe R. K., Pacala S. W., Silander J. A., Canham C. D. Ecological Applications. 1995, vol. 5, pp. 517-532.

18. Liu Q. J. China. Plant Ecology. 1997, vol. 132, pp. 97-105.

19. Kulakowski D. P., Rixen C., Bebi P. For. Ecol. Manag. 2006, vol. 223 (1), pp. 66-74.

20. Splechtna B. E., Gratzer G., Black B. A. J. Veg. Sci. 2005, vol. 16, pp. 511-522.

21. Black A. B., Abrams M. D., Rentch J. S., Gould P. J. Ann. For. Sci. 2009, vol. 66 (2), pp. $205-216$.

22. Koryakin N. V. Korean pine-broadleaved forests of the Russian Far East. Khabarovsk: Federal State Institution "Far East Research Institute of Forestry", 2007, 359 p. [in Russian]

23. Kudinov A. I. Korean pine-broadleaved forests of Southern Primorye and their dynamics. Vladivostok: Dalnauka, 2004, 369 p. [in Russian]

24. Omelko A. M., Ukhvatkina O. N., Zhmerenetsky A. A., Petrenko T. Ya. For. Ecol. and Manage. 2018, vol. 411, pp. 46-66.

25. Ishikawa Y., Krestov P. V., Namikawa K. Journal of Vegetation Science. 1999, vol. 10, pp. 439-448.

26. Ukhvatkina O. N., Omelko A. M., Krestov P. V., Zhmerenetsky A. A. Journal of the Siberian Federal University: Biology. 2011, no. 4 (4), pp. 416-431. [in Russian]

27. Zhang Y., Drobyshev I., Gao L., Zhao X., Bergeron Y. Dendrochronologia. 2014, vol. 32, pp. $21-31$.

28. Zhou Q., Shi H., Liu C., Zhang K., Zhang Q., Dang H. Dendrochronologia. 2018, vol. 50, pp. 91-97.

29. Kolesnikov B. P. Works of FEF SB AN USSR. Botanical Series. 1956, no. 2, vol. 4, 262 p. [in Russian] 
30. Omelko A. M., Ukhvatkina O. N., Zhmerenetsky A. A. Forest Ecology and management. 2016, vol. 360, pp. 221234.

31. Kozhevnikova N. K. Siberian Journal of Ecology. 2009, no. 5, pp. 693-703. [in Russian]

32. Holmse R. L. Tree-Ring Bull. 1983, vol. 43, pp. 69-78.

33. Komarova T. A., Ukhvatkina O. N., Trofimova A. D. Bul. Bot. Garden-Institute FEB RAS. 2010, no. 5, pp. 81-92. [in Russian]

34. Komarova T. A., Ukhvatkina O. N., Trofimova A. D., U-San. Kim Bulletin of the Botanical Garden-Institute of the Far Eastern Branch of the Russian Academy of Sciences. No. 5, pp. 93-101. [in Russian]

35. Ukhvatkina O. N., Komarova T. A., Trofimova A. D. Bulletin of Moscow State Forest University. 2010, no. 3, pp. 169-173. [in Russian]

36. Omelko A. M., Ukhvatkina O. N., Zhmerenetsky A. A., Gusev V. S. Basic research: Biological sciences. 2013, no. 11, pp. 443-447. [in Russian]

37. Zhmerenetsky A. A., Omelko A. M., Ukhvatkina O. N., Petrenko T. Y. Russian journal of ecosystem ecology. 2018, vol. 3 (1), pp. 1-11. [in Russian]

38. Zhmerenetsky A. A., Omelko A. M., Ukhvatkina O. N., Petrenko T. Ya., Sibirina L. A. Plant resources. 2018 , no. 54 (2), pp. 260-279. [in Russian]

39. Black B. A., Abrams M. D. Ecological Applications. 2003, vol. 13, pp. 1733-1749.

40. Black B. A., Abrams M. D. Dendrochronologia. 2004, vol. 22, pp. 31-42.

41. Nowacki G. J., Abrams M. D. Ecol. Monogr. 1997, vol. 67, pp. 225-249.

42. Altman J., Fibich P., Dolezal J., Aakala T. Dendrochronologia. 2014, vol. 32, pp. 107-112.

43. Yang G. T., Erich H., Sun B., Zhang J. Bull. Bot. Res. 1994, vol. 14, pp. 313-328.

44. Zielonka T., Holeksa J., Fleischer P., Kapusta P. Journal of Vegetation Science. 2010, vol. 21, pp. 31-42.

45. Ukhvatkina O. N., Omelko A. M., Zhmerenetsky A. A., Gusev V. S. Journal of the Siberian Federal University: Biology. 2015, no. 4 (8), pp. 441-458. [in Russian]

46. Zielonka T., Malcher P. Can. J. For. Res. 2009, vol. 39, pp. 2215-2223.

47. Zhao X. H., Zhang C. Y., Zheng J. M. Frontiers of Forestry in China. 2006, vol. 4, pp. 372-378.

48. Chumachenko S. I., Yakovleva A. I. Bulletin of the Irkutsk state Agriculture Academy. 2014, vol. 61, pp. 74-80. [in Russian]

49. Ukhvatkina O. N., Omelko A. M. Bulletin of Tomsk State University. Biology. 2016, vol. 4 (36), pp. 164-179. [in Russian]

50. Usenko N. V. Trees, shrubs and vines of the Far East. Khabarovsk: Khabarovsk Book Publishing House, 1984, 272 p. [in Russian]

51. Dejan F., Thomasa N., Jurij D. For. Ecol. Manage. 2009, vol. 257, pp. 1893-1901.

52. Svoboda M., Janda P., Nagel T. A., Fraver S., Rejzek J., Ba R. J. Veg. Sci. 2012, vol. 23, pp. 86-97.

53. Nagel T. A., Svoboda M., Kobal M. Ecol. Appl. 2014, vol. 24, pp. 663-679.

54. Petritan A. M., Bouriaud O., Frank D. C., Petritan I. C. J. Veg. Sci. 2017, vol. 28, pp. 318-331.

55. Kozin E. K. Bull. Bot. Garden - Institute FEB RAS. 2013, vol. 10, pp. 4-14. [in Russian]

56. Longshore D. Infobase Publishing. 2008, 481 p. 